\title{
ONYCHOPHORA IN HUMID FORESTS OF NORTHEASTERN BRAZIL
}

\author{
VASCONCELLOS, A ${ }^{1}$, ALMEIDA, W. O. ${ }^{2}$ and SOUZA, L. A. ${ }^{2}$ \\ ${ }^{1}$ Departamento de Sistemática e Ecologia, Universidade Federal da Paraíba, CCEN, João Pessoa, PB, Brazil \\ ${ }^{2}$ Departamento de Ciências Físicas e Biológicas, Universidade Regional do Cariri, Crato, CE, Brazil \\ Correspondence to: Alexandre Vasconcellos, Departamento de Botânica, Ecologia e Zoologia, CB, \\ Universidade Federal do Rio Grande do Norte, CEP 59072-970, Natal, RN, Brazil, \\ e-mail: avasconcellos@cb.ufrn.br
}

Received April 20, 2004 - Accepted June 22, 2004 - Distributed February 28, 2006

(With 1 figure)

Onychophora are soft-bodied terrestrial invertebrates, commonly known as velvet-worms because of their smooth appearance. They live predominantly in tropical regions, mainly in humid forests and caves (Newsland \& Ruhberg, 1979). In forest ecosystems, onycophorans are found beneath leaf litter and stones, in or under rotting logs, and in retreats of burrows in the soil, bromeliads, and at the base of live tree trunks (Newsland \& Ruhberg, 1979; Ruhberg, 1992). They are predators and lucifugus organisms that leave their shelters at twilight to feed on small invertebrates such as termites, crickets, cockroaches, isopods, earthworms, and beetle larvae (Hamer et al., 1997).

Onycophorans were categorized by Wells et al., (1983) as vulnerable organisms, indicating the need for prioritizing their conservation among the terrestrial invertebrates. This vulnerability may be due to the fact that their habitats are highly susceptible to destruction and their populations small and fragile. Whatever the viewpoint of biologists regarding the issue of conservation, Onychophora indisputably represent one of the key groups for our comprehension of the phylogeny of the Arthropoda (Monge-Nájera \& Hou, 1999; Almeida et al., 2003). As pointed out by Hill (1950), Ghiselin (1985) and New (1995), Onychophora can also be considered 'living fossils' since the morphology of live species still preserve many of the structural features of fossil species.

In the present work, eleven onychophoran specimens, all belonging to the genus Peripatus, were recorded at eight sites in humid forests in four states of northeastern Brazil (Fig. 1). The study sites were located in i) Brejo dos Cavalos, Caruaru, $\mathrm{PE}\left(08^{\circ} 22^{\prime} \mathrm{S}\right.$ and $\left.36^{\circ} 2^{\prime} \mathrm{W}\right)$; ii) Reserva Biológica de Pedra Talhada, Quebrangulo, AL $\left(09^{\circ} 15^{\prime} \mathrm{S}\right.$ and $\left.36^{\circ} 25^{\prime} \mathrm{W}\right)$; iii) Horto Dois Irmãos, Recife, $\mathrm{PE}\left(07^{\circ} 07^{\prime} \mathrm{S}\right.$ and $\left.34^{\circ} 51^{\prime} \mathrm{W}\right)$; iv) Brejo de Bezerros, Bezerros, PE ( $08^{\circ} 11^{\prime} \mathrm{S}$ and $\left.35^{\circ} 47^{\prime} \mathrm{W}\right)$; v) Mata de Murici, $\mathrm{PE}\left(09^{\circ} 15^{\prime} \mathrm{S}\right.$ and $\left.35^{\circ} 51^{\prime} \mathrm{W}\right)$; vi) Serra da Jibóia, Santa Terezinha, BA $\left(12^{\circ} 48^{\prime} \mathrm{S}\right.$ and $39^{\circ} 34^{\prime} \mathrm{W}$ ); vii) Mata do Catolé, Maceió, AL $\left(09^{\circ} 40^{\prime} \mathrm{S}\right.$ and $\left.35^{\circ} 44^{\prime} \mathrm{W}\right)$; and viii) Chapada do Araripe, Crato, $\mathrm{CE}\left(07^{\circ} 13^{\prime} \mathrm{S}\right.$ and $\left.39^{\circ} 38^{\prime} \mathrm{W}\right)$. The first seven areas are part of the realm of the Atlantic Forest; some of them, however, are considered "Brejos de Altitude" (a kind of highland humid forest), included in the "Caatinga" realm ("caatinga" is dry scrub forest with thorny shrubs and stunted trees). The Onychophora studied here belong to the collection of invertebrates housed in the Universidade Federal da Paraíba, Departamento de Sistemática e Ecologia.

The onychophoran specimens were collected from rotting tree trunks, leaf litter or abandoned termite nests. A combination of factors, such as reduced penetration of sunlight, tree trunks in different stages of decomposition, thick leaf layer on soil, active and non-active termite nests, besides bryophytes, pteridophytes, bromeliads and lianas in the vegetation, were predominant at the collection sites where onychophorans were found.

Although we recognize the importance of understanding the evolution of metazoans, few studies on the natural history, taxonomy and ecology of Onychophora have been carried out in the Neotropical region, and Brazil is a classical example (Peck, 1975). According to New (1995), some of the main obstacles to achieving progress in the knowledge of this taxon are: i) difficulty to identify the species, even at the generic level, due to lack of consistent morphological characteristics; ii) difficulty of appropriate sampling due to low 


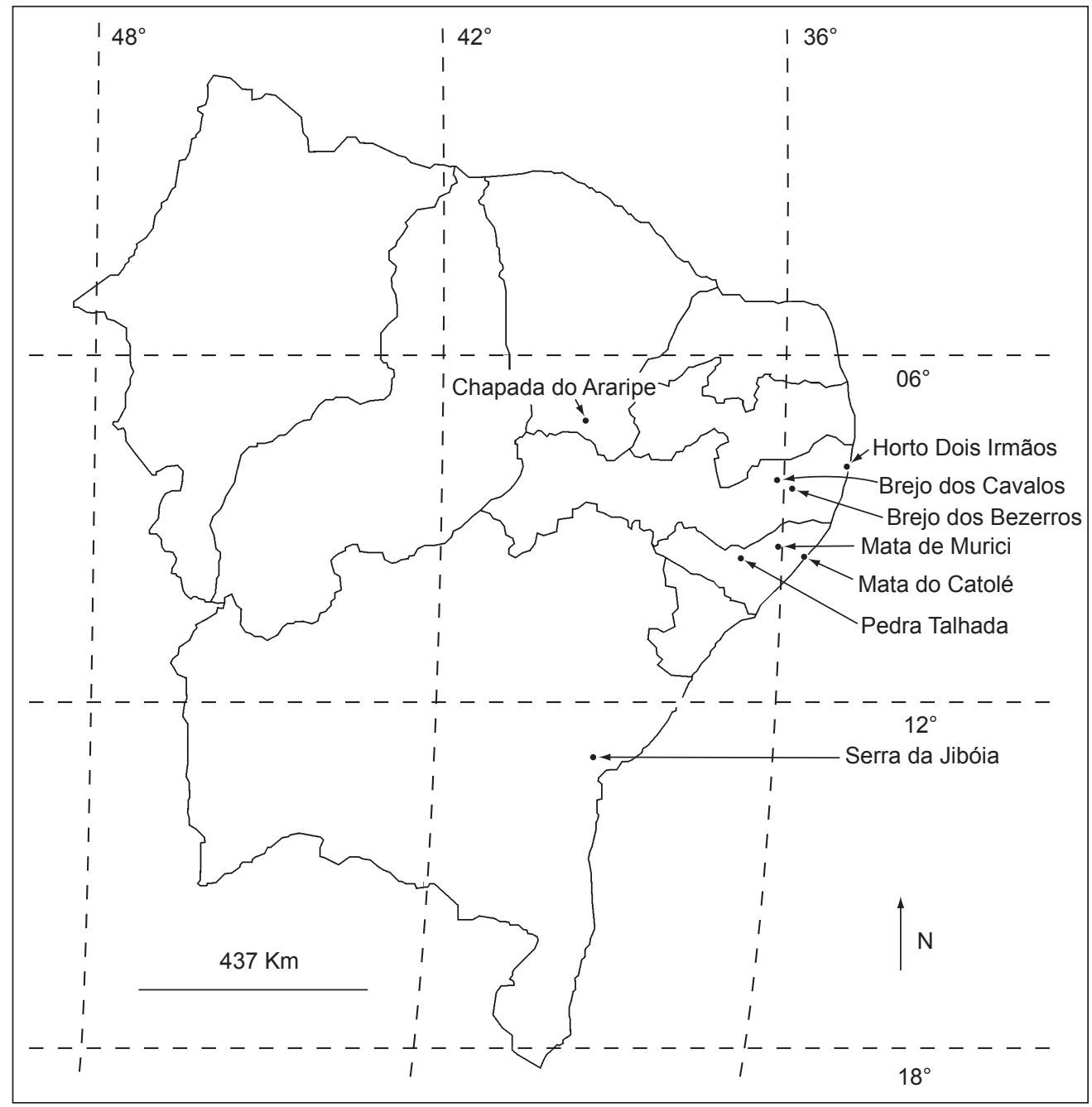

Fig. 1 - Distribution of humid forests of northeastern Brazil where the Onychophora were found.

population densities of most species; iii) their inability to withstand desiccation, making them sensitive to sunlight and most active at night; and iv) nothing is known about the influence of climatic seasonality on the individual's activities.

The recording of onychophorans in Brazil's northeastern humid forests is highly relevant for our understanding of their distribution in the Neotropical region. Furthermore, the lack of resilience of onycophorans to harsher environments and their small population sizes reinforce the need to preserve their habitats, which would simply be the consequence of a broader preservation of ecosystems, founded on precise ecological requirements of local fauna and their importance in the maintenance of ecological processes. The results thus obtained would encourage new investigations on the taxonomy, life history and interesting ecological aspects relating to invertebrate conservation, such as the population dynamics of onycophoran species.

Acknowledgments - We are grateful to $\mathrm{CNPq}$ for the grant conceded to Alexandre Vasconcellos; to Dr. Freddy Bravo (UEFS), to Mr. Sidclay C. Dias (MSc), and to Mr. Fagner R. Delfim (Biologist) for useful information on the natural history of onycophorans; and to Dr. Breno Grisi for the English version of the manuscript. 


\section{REFERENCES}

ALMEIDA, W. O., CHRISTOFFERSEN, M. L., AMORIM, D. S., GARRAFFONI, A. R. S. \& SILVA, G. S., 2003, Polychaeta, Annelida, and Articulata are not monophyletic: Articulating the Metameria (Metazoa: Coelomata). Rev. Bras. Zool., 20(1): 23-57.

GHISELIN, M. T, 1985, A movable feaster. (New York, USA). Natural History 94(9): 54-61.

HAMER, M. L., SAMWAYS, M. J. \& RUHBERG, H., 1997, A review of the Onychophora of South Africa, with discussion of their conservation. Annals of the Natal Museum, 38: 283-312.

HILL, R. P., 1950, Peripatus: A missing link. Discovery, 11(1): 14-18.

MONGE-NÁJERA, J. \& HOU, X. G., 1999, 500 millones de años de evolución: onicoforos, los primeros animales que caminaron (Onychophora). Boletin de la SEA, 26: 171-176
NEW, T. R., 1995, Onychophora in invertebrate conservation: Priorities, practice and prospects. Zool. J. Linn. Soc., 114(1): 77-89.

NEWLANDS, G. \& RUHBERG, H. S., 1979, Onychophora, pp. 677-684. In: M. J. A. Werger (ed.), Biogeography and Ecology of Southern Africa, Part 2 (Monographiae Biologicae, vol. 31, part 2). Dr. W. Junk Publishers: The Hague, Netherlands.

PECK, S. B., 1975, A review of the New World Onychophora, with the description of a new cavernicolous species and genus from Jamaica. Psyche, 82: 341-358.

RUHBERG, H., 1992, Peripatus - an approach towards a modern monograph, pp. 441-458. In: E. Meyer, K. Thaler \& W. Schedl (eds.), Advances in Myriapodology: Proceedings of the $8^{\text {th }}$ International Congress of Myriapodology (Supplementum 10). Berichte des Naturwissenschaftlich-Medizinischen, Vereins Innsbruck.

WELLS, S. M., PYLE, R. M. \& COLLINS, N. M., 1983, The IUCN Invertebrate Red Data Book. Cambridge, IUCN. 